Jurnal Belantara Vol. 5, No.1, March 2022 (59-71)

E-ISSN 2614-3453

DOI: $\underline{10.29303 / \mathrm{jbl} . v 5 i 1.889}$

P-ISSN 2614-7238

\title{
SOIL CHARACTERISTICS OF SIX FOREST MANAGEMENT REGIMES IN LOMBOK, INDONESIA
}

\author{
Sitti Latifah*, Eni Hidayati, Niechi Valentino \\ ${ }^{1}$ Forestry Study Program, University of Mataram, Mataram, Indonesia \\ *e-mail: sittilatifah@unram.ac.id
}

Received : 23/02/2022, Revised : 28/02/2022, Approved : 05/03/2022

\begin{abstract}
A good quality top soil is important for optimum plant growth in any land-use type. The landscape in Karang Sidemen Village, located at the bottom of Rinjani volcano, consists of a mosaic of management regimes. This study assessed the soil profile and properties of six management regimes under different governing bodies, namely, secondary forest, monoculture stand, agroforestry in KHDTK Rarung, agroforestry in community forest, banana-dominant landscape in Hortipark Tastura, and mixed planted forest. Soil profile and $\mathrm{pH}$ data were collected from a two-dimensional soil wall $(100 \mathrm{~cm}$ depth). Soil samples from $30 \mathrm{~cm}$ depth of each forest were analyzed for the soil properties (soil organic carbon, bulkdensity, soil water content, litter biomass). The results showed that the vertical $\mathrm{pH}$ in the soil profile is generally increasing or steady from top to bottom except for the secondary forest. The $\mathrm{pH}$ value ranged from 5.0 to 7 . The soil colors are mostly in the yellow-red category. The soil in the six management regimes is still ideal for plant growth indicated by its low bulk density and ideal $\mathrm{pH}$ range for plant growth. Soil organic carbon is highest in the secondary forest which corresponds to $7.5 \mathrm{YR} 3 / 1$ and lowest in the monoculture stand (10YR $2 / 2$ ). Soil water content is highest in the secondary forest and lowest in the agroforestry in KHDTK Rarung. The litter biomass in the secondary forest is two times higher than in agroforestry sites and four times higher than in banana-dominant landscape, monoculture stand and mixed planted forest.
\end{abstract}

Keywords: Landscape-based approach, Rinjani volcano, soil organic carbon, soil profile

\section{INTRODUCTION}

Upstream-downstream linkages occur at different scale and in many aspects including the socioeconomic, environment, institutional and cultural aspects (Nepal et al., 2018). The upper stream communities often face challenges in ensuring their livelihoods. On one hand, the forests in the upstream areas are important for water catchment and carbon sequestration, hence must be protected. On the other hand, livelihood strategy choices are limited (Afifah et al., 2021; Ansharyani, 2018; Ichsan et al., 2013; Hidayati, 2012). Communities living around Rinjani volcano in Lombok, Indonesia, are expected not to perform livelihood activities that may pose adverse impacts on the environment such as clear cut of the forest because the 
catchment areas located at the bottom of the Rinjani volcano plays a key role in regulating water flow (source of water) for the downstream communities (FAO, 2013; Nini, et al., 2022).

Landscape approaches seek to accommodate balance in economic, ecological and socio-cultural aspects (Svensson, et.al., 2020). Embracing integrated land-sharing philosophy, the landscape approaches have been promoted as an alternative to conventional, sectoral land-use planning, policy, governance, and management (Reed and Deakin, 2015). A multifunctional landscape simultaneously meets a broader range of local needs including ensuring water availability and regulation; providing biodiversity for crop pollination and tourism; producing nutritious and profitable crops and at the same time meeting global target commitment such as climate change mitigation (UNEP, 2017; Kim, Y.S. et al., 2018). A good soil quality is important to achieve the various needs that a multi-functional landscape tries to meet. Soils provide essential contributions to life like food, clean water, and are a major carrier for biodiversity and is significant for the realization of Sustainable Development Goal (Keesstra, et.al., 2016).

Karang Sidemen is one of the villages located at the buffer zone of the Mount Rinjani National Park (MRNP). The landscape in Karang Sidemen village consists of a mosaic of management regimes with different governing bodies such as the Mount Rinjani National Park (MRNP), Forest Park Conservation Area (Tahura) Nuraksa, Hortipark Tastura, Forest for Specific Purpose (Kawasan Hutan Dengan Tujuan Khusus-KHDTK) Rarung, and Community Forestry. Within each governing body, different land-use types also exist. Each governing body has their own purpose(s).

A recent global study shows that more than 90 per cent of the conventionally farmed soils were thinning and 16 per cent had lifespans of less than 100 years (Evans et al., 2020). Therefore, it is important to study the soil properties of different management practices. Previous study in Karang Sidemen village, focusing on one management practice (i.e. community forestry), evaluated the impacts of community forestry on runoff and erosion from 2007 to 2015 (Nandini, et.al., 2019) . Their study shows that there is a slight decrease in runoff and erosion rate from 2007 to 2015. Studies to analyze the soil properties of different management practices over time have not been conducted. This study will assess the soil profile and properties as the baseline data in six different management regimes in the buffer zone of Mount Rinjani National Park (MRNP), North Lombok, Indonesia. The results of this study will enrich the information needed to assess management practices' impacts on the environment particularly the soil over time.

\section{METHOD}

\section{Site description}

This study was carried out in 2020-2021 in Karang Sidemen Village, located at the buffer zone of Mount Rinjani National Park (MNRP), Lombok, Indonesia (Figure 1). Six management regimes purposively selected in this study were (i) Secondary tropical dry forest, (ii) Monoculture stand of Diospyros malabarica, (iii) Banana-dominant landscape in Hortipark Tastura, (iv) Agroforestry in KHDTK Rarung, (v) Mixed planted forest, and (vi) Agroforestry in Community Forestry (Hutan Kemasyarakatan). These management practices are all found in Karang Sidemen Village but managed by different actors/institutions. The secondary tropical dry forest in this study is under the management of Forest Park Conservation Area (Tahura) Nuraksa. The monoculture 
of $D$. malabarica stand and mix planted forest are within KHDTK Rarung (also owned and managed by the government). The D. malabarica were planted in 1994. The banana-dominant area is within the Hortipark (owned by the government but partly managed by the community group). One agroforestry site is owned by KHDTK Rarung but managed by the community group. One agroforestry site is under the Community Forest Management scheme.

\section{Soil sampling and analysis}

To study the soil profile, a two-dimensional soil vertical cross-section with $100 \mathrm{~cm}$ depth (Smith, 1960) was used in each management regimes. The spot in each site was selected randomly (Figure 2). The soil profile data were collected on September 2021. Soil pH for each horizon was gained using soil $\mathrm{pH}$ meter. To assess some soil properties, soil samples $(0-30$ $\mathrm{cm}$ ) were collected at each site, mixed thoroughly, homogenized and stored. These sample soils were air-dried, ground and then passed through a 2-mm sieve to remove gravel and boulders. To obtain SOC content, soil samples are processed and analyzed using spectrophotometer and calculated with the following formula (Sulaeman, et al., 2006):

$$
\% \mathrm{C}=\text { ppm curve } \times(100 / \text { weight }) \times 0.0001 \times \text { Correction factor }
$$

Bulk density and soil water content were determined using volumetric ring method (Grossman, 2002). To identify the soil color, a portion of soil in each soil horizon was hold up to the Munsell chart. The soil dry color was identified under all full sun. First, the hue was identified, then the value, and lastly the chroma. The Red Index (RF) of the A Horizon was determined according to Santana (1984).

$$
\mathrm{RF}=(10-\mathrm{H})+\mathrm{C} / \mathrm{V}
$$

Where:

$\mathrm{RF}=$ Red Index of soil $\quad \mathrm{C}=$ Value of Chroma (Munsell Chart)

$\mathrm{H}=$ Value of Hue (Munsell Chart) $\quad \mathrm{V}=$ Value of Value (Munsell Chart)

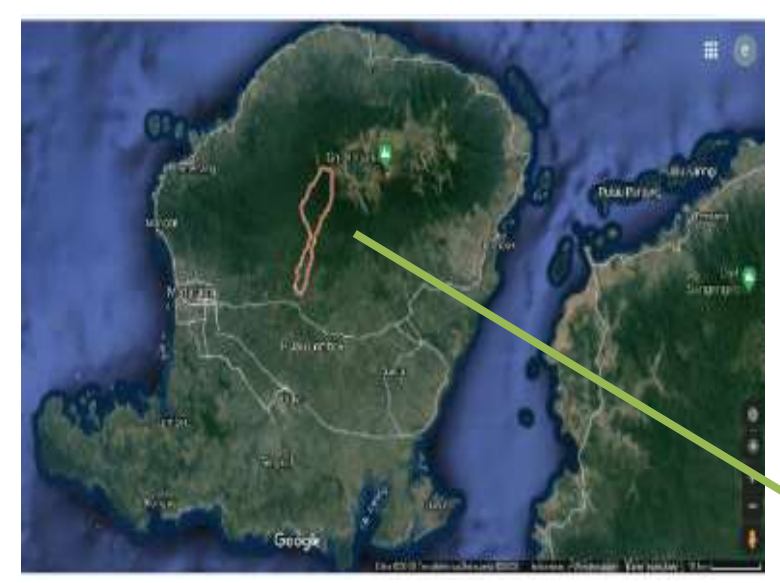

Figure 1. Karang Sidemen Village

Karang Sidemen Village

Source: Google Map 2021. Scale 1: 2,000,000

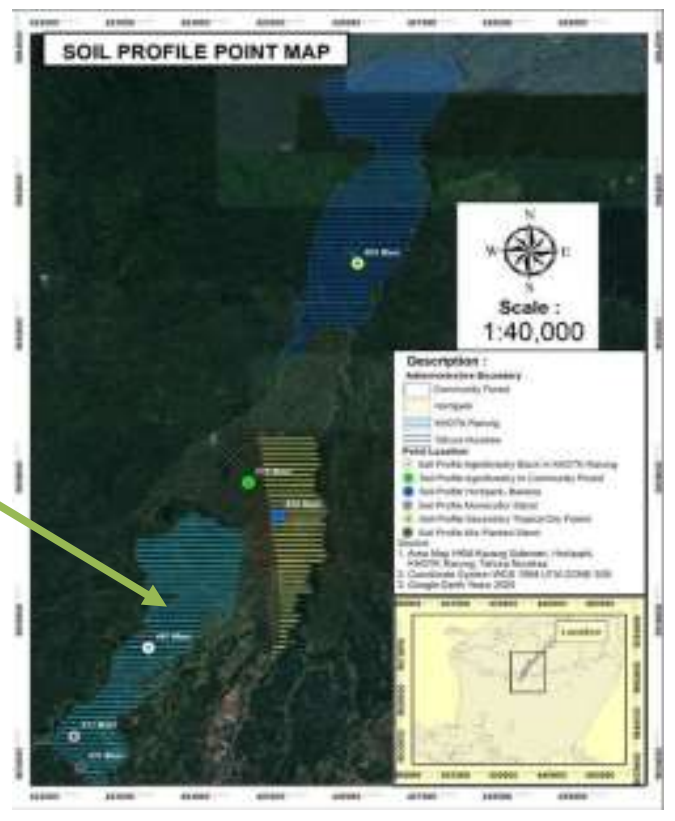

Figure 2. Soil Sampling Location 


\section{Forest litter biomass}

Forest litter samples were collected from a $50 \mathrm{~cm}$ x $50 \mathrm{~cm}$ plot selected randomly in each study site to acquire 300 grams of litter (Randi, 2018). Forest litter biomass were estimated by measuring the wet weight and constant oven dry weight (Manuri, et.al., 2011). The litter biomass figure in this study is the constant oven dry weight.

\section{RESULTS AND DISCUSSION}

\section{Soil Profile and $\mathrm{pH}$}

Six soil profiles studied show that the soil colors can be easily differentiated, most notably for the secondary forest and agroforestry in community forest soil profiles (Figure 3a-f). Table 1 presents some morphological soil features. The colors are mostly in the Yellow Red spectrum. The top soil depth of the secondary forest (around $15 \mathrm{~cm}$ ) is significantly different from the other profiles (around $4 \mathrm{~cm}$ ). Fine roots can be found up to the B3 horizon. The top soil in the secondary forest is also darker (7.5 YR 3/1) than all other sites' topsoil.

Table 1. The descriptions of the soil profiles in six management practices

\begin{tabular}{llll}
\hline Horizon & Depth $(\mathbf{c m})$ & Color & Structure \\
\hline & Soil Profile 1 (Secondary forest) & & \\
A & $0-15$ & 7.5 YR 3/1 & Granular \\
B1 & $15-47$ & 7.5 YR 3/2 & SB \\
B2 & $47-70$ & 7.5 YR 3/4 & SB \\
B3 & $70-100$ & 7.5 YR 2/3 & SB
\end{tabular}

Soil Profile 2 (Agroforestry in CF)

$\begin{array}{llll}\text { A } & 0-4 & 10 \text { YR 2/2 } & \text { Granular } \\ \text { B1 } & 4-12 & 7.5 \text { YR 3/5 } & \text { SB } \\ \text { B2 } & 12-40 & 10 \text { YR 4/6 } & \text { SB } \\ \text { B3 } & 40-70 & 10 \text { YR 5/6 } & \text { SB } \\ \text { C } & 70-100 & 2.5 \text { Y 4/4 } & \text { Blocky }\end{array}$

Soil Profile 3 (Hortipark - banana)

$\begin{array}{llll}\text { A } & 0-8 & 7.5 \text { YR 5/2 } & \text { Granular } \\ \text { B1 } & 8-21 & 5 \text { YR 3/2 } & \text { SB } \\ \text { B2 } & 21-50 & 7.5 \text { YR 3/4 } & \text { SB } \\ \text { B3 } & 50-100 & 7.5 \text { YR 5/4 } & \text { SB }\end{array}$

Soil Profile 4 (Agroforestry in KHDTK

\section{Rarung)}
A
0-7
B1
$7-32$
10 YR 2/2 Granular
$10 \mathrm{YR} 3 / 3 \quad \mathrm{SB}$ 


$\begin{array}{llll}\text { B2 } & 32-74 & 7.5 \text { YR 3/3 } & \text { SB } \\ \text { B3 } & 74-100 & 10 \text { YR 4/2 } & \text { SB }\end{array}$

\section{Soil Profile 5 (Mix planted stand)}

$\begin{array}{llll}\text { A } & 0-7 & 5 \text { YR 3/3 } & \text { Granular } \\ \text { B1 } & 7-40 & 10 \text { YR 4/4 } & \text { SB } \\ \text { B2 } & 40-70 & 10 \text { YR 3/2 } & \text { SB } \\ \text { B3 } & 70-100 & 7.5 \text { YR 3/1 } & \text { SB }\end{array}$

\section{Soil Profile 6 (Monoculture stand)}

\begin{tabular}{llll} 
A1 & $0-4$ & 10 YR 2/2 & Granular \\
B1 & $4-24$ & 10 YR 3/2 & SB \\
B2 & $24-50$ & 7.5 YR 3/3 & SB \\
& $50-90$ & 7.5 YR 4/4 & SB \\
B3 & $90-126$ & 7.5 YR 3/2 & SB \\
\hline
\end{tabular}

${ }^{1}$ The descriptions of soil color followed the Munsell Soil Color Charts; ${ }^{2}$ Code for types of soil structure was used: SB-Subangular blocky.

Soil $\mathrm{pH}$ is generally increasing from the top of the soil profile to the bottom, except for secondary forest. The $\mathrm{pH}$ values are between 5 (strongly acidic) to 7 (neutral) (Figure 3a-f). Soil pH was steady or increased with soil depth in five soil profiles, which was consistent with what many studies have found (Crane and Balerdi, 2019; Zhang, 2019). In soil profiles of humid environments with parent materials containing appreciable concentrations of bases, it is common to observe increasing values of soil $\mathrm{pH}$ with depth in the profile due to the leaching of soluble bases (Singh, 2014).

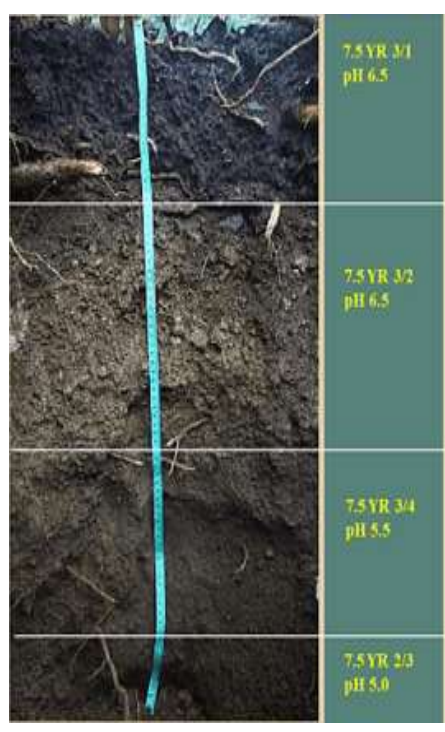

(a)

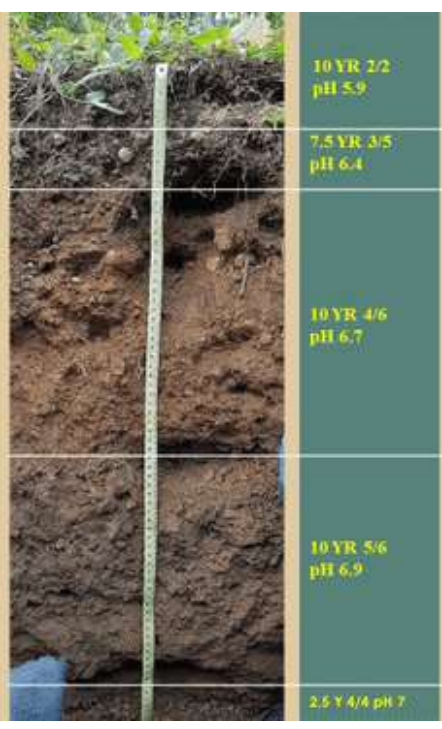

(b)

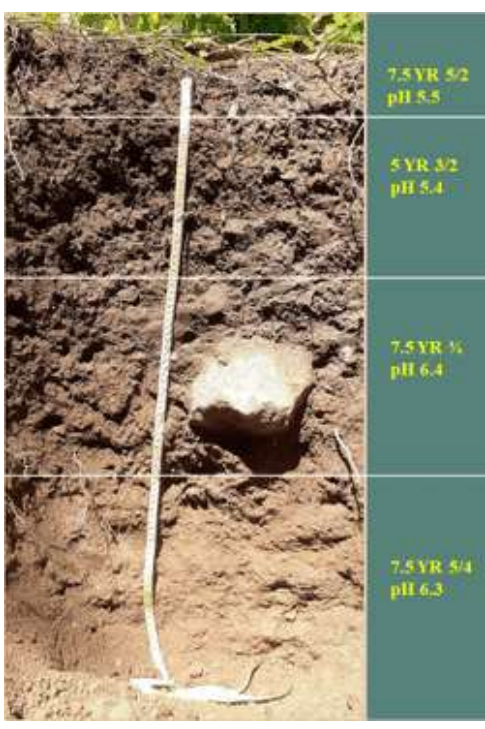

(c) 


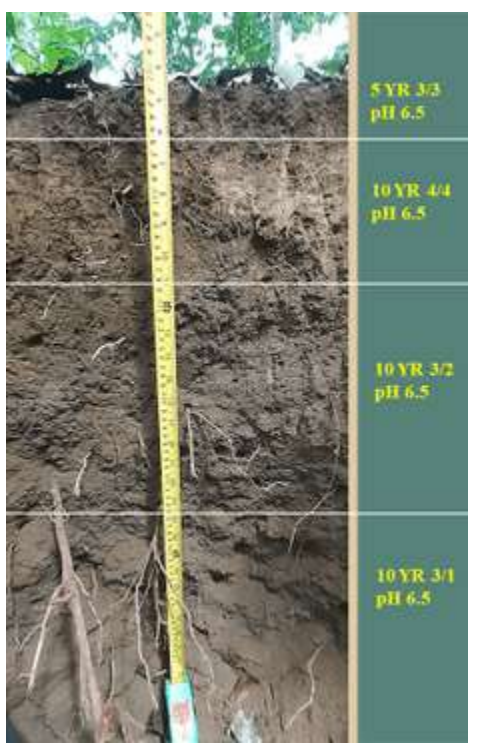

(d)

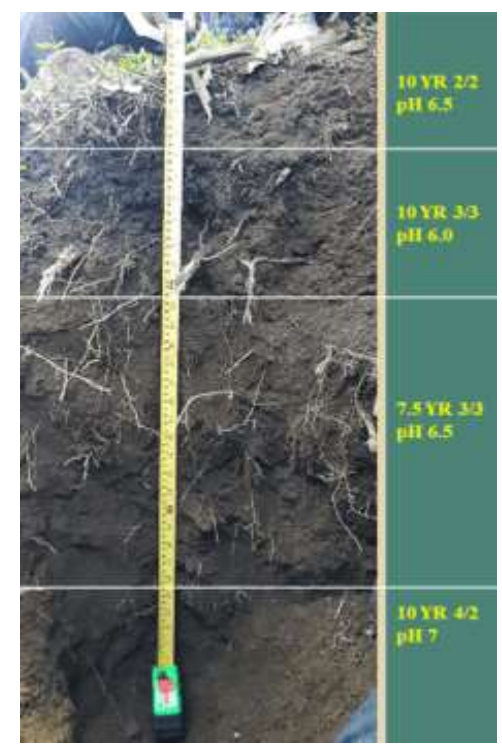

(e)

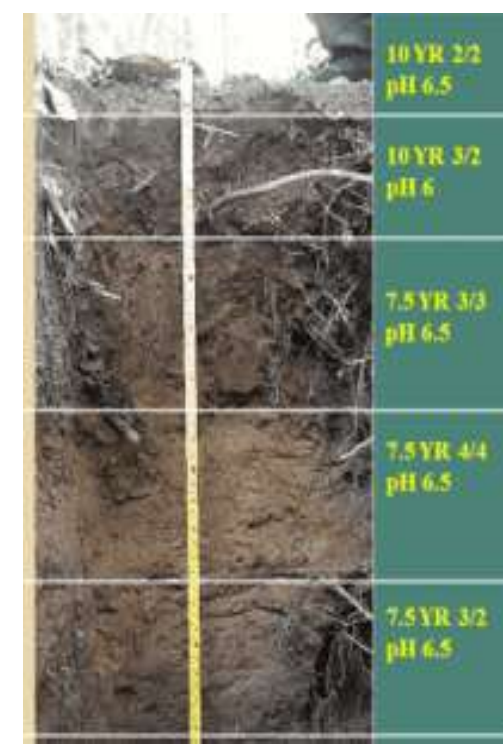

(f)

Figure 3. Soil profile and its $\mathrm{pH}$. (a) Secondary forest, (b) Agroforestry in Community Forest Management, (c) Hortipark Tastura - banana (d) Agroforestry in KHDTK Rarung (e) Mixed planted stand in KHDTK Rarung, (f) Monoculture stand of D. Malabarica in KHDTK Rarung

While for the secondary tropical dry forest, the soil $\mathrm{pH}$ decreased with soil depth. This is consistent with other studies in the tropical forest where this paradoxical relationship is commonly observed between massive biomass production and low soil pH (Terborgh,1992), for example, in Bornean tropical forest, soil acidification is promoted by plants and microorganisms as a nutrient acquisition strategy, while plant roots and fungi can develop rhizosphere and enzymatic processes that promote tolerance of low pH (Fuji, 2014).

According to their $\mathrm{pH}$ value, soils can be classified as neutral $(6.5-7.5)$, alkaline (7.5), acidic (less than 6.5) and strongly acidic (less than 5.5) (Q., 2016). Some nutrients are more available under acid conditions while others are more available under alkaline conditions (Q., 2016) but most minerals and nutrients are more soluble or available in acid soils than in slightly alkaline soils (Bickelhaupt, 2020). pH 6 to 8 is the general range where nutrient availability is optimal (Läuchli and Grattan, 2012).

This study indicates that the soil $\mathrm{pH}$ in almost all management regimes (ranges from 5.0 to 7.0) are suitable for plant growth. However, attention should be directed to hortipark where the dominant species is banana. Bananas do best on flat (slope $0-1 \%$ ), well drained, deep soils high in organic matter with a $\mathrm{pH}$ of 5.5-7.0 (Crane and Balerdi, 2019). The $\mathrm{pH}$ in the bananadominant soil profile in this study from top to bottom is $5.5 ; 5.4 ; 6.4$ and 6.3 . It shows that planting banana is suitable for the soil condition. While this range is still optimal for banana, the $\mathrm{pH}$ needs to be monitored as the top soil's $\mathrm{pH}$ is right at the lower bound of the optimum range and study has shown that banana perform better with higher pH above 5.7 (Segura, et.al., 2015). This is important because income from banana comprises the biggest portion of their income which is around 54,8\% (Nandini, et.al., 2019). As they don't use fertilizers, the low $\mathrm{pH}$ 
might be natural due to parent material or leaching. To improve productivity, they might want to look at the soil $\mathrm{pH}$ and texture.

\section{Soil RF index , BD, SWC, SOC and Litter Biomass}

Soil BD, SWC, and SOC are varied among the management practices (Table 2). The SWC is highest in the secondary forest and lowest in the agroforestry (KHDTK Rarung). The Bulk Density is highest in the agroforestry (KHDTK Rarung) and lowest in the secondary forest. The SOC in highest in the secondary forest $(10.56 \%)$ and lowest in the monoculture stand of $D$. malabarica stand (3.7\%). While five other management practices are approximately half of the secondary forest value. The litter biomass in the secondary forest is two times higher than in agroforestry sites and four times higher than in banana-dominant landscape, monoculture stand and mixed planted forest.

Table 2. Soil properties in six management practices

\begin{tabular}{lllllll}
\hline Management Practices & SWC (\%) & BD $\left(\mathbf{g} / \mathbf{c m}^{3}\right)$ & SOC (\%) & $\begin{array}{l}\text { Litter } \\
\text { Biomass } \\
\text { (ton/ha) }\end{array}$ & $\begin{array}{l}\text { pH } \\
\text { Topsoil }\end{array}$ & $\begin{array}{l}\text { RF } \\
\text { index }\end{array}$ \\
\hline Secondary forest & 81.31 & 0.39 & 10.56 & 4.84 & 6.5 & 2.8 \\
Agroforestry (CF) & 61.48 & 0.54 & 4.26 & 2.8 & 5.9 & 1 \\
Hortipark Tastura & 43.67 & 0.61 & 5.16 & 1.48 & 5.5 & 2.9 \\
Mixed planted forest & 40.82 & 0.59 & 4.19 & 1.2 & 6.5 & 6 \\
Monoculture stand & 36.91 & 0.65 & 3.7 & 1.2 & 6.5 & 1 \\
Agroforesty (KHDTK Rarung) & 31.72 & 0.75 & 4.31 & 2.04 & 6.5 & 1 \\
\hline
\end{tabular}

Source : primary measurement (2021)

Note: Soil Water Content (SWC), Bulk Density (BD), Soil Organic Carbon (SC)

Pearson correlation performed on soil properties (Table 3 ) shows some significant correlation among the soil properties.

Table 3. Correlation among soil properties

\begin{tabular}{llllll}
\hline & SWC & BD & SOC & Litter Biomass & $p H$ \\
\hline SWC & 1.000 & & & & \\
BD & $-0.954^{*}$ & 1.000 & & \\
SOC & $0.841^{* *}$ & $-0.808^{* *}$ & 1.000 & & \\
Litter Biomass & $0.881^{* *}$ & -0.732 & $0.880^{* *}$ & 1.000 & \\
$p H$ & -0.041 & 0.028 & 0.155 & 0.174 & 1.000 \\
\hline
\end{tabular}

${ }^{*}$ correlation is significant at the 0.01 level

${ }^{* *}$ correlation is significant at the 0.05 level

SWC and BD directly influence plant performance because they affect the chemical and biological properties of soil (Bonfante et al. 2019; Chakraborty and Mistri, 2017). Soil bulk is 
often regarded as one of the soil health indicators (Bonfante et al. 2019). Lower bulk density allows more optimum plant growth (Anda, 2021). This study observed a strong reciprocal relationship between soil water content and bulk density $(R=-0.954)$ at significant level 0.01 . This finding is consistent with other studies conducted on fields (Anda, 2021) and in laboratories (Abidin et al. 2013; Ghosh, 2013). Increase in soil bulk density will reduce the soil water content. The BD value in this study ranges from $0.39 \mathrm{~g} / \mathrm{cm}^{3}$ (in secondary forest) to $0.75 \mathrm{~g} / \mathrm{cm}^{3}$ (in Agroforestry KHDTK Rarung). This value is inversely correlated to the SWC values where the SWC is highest in the secondary forest (81.31\%) and lowest in the Agroforestry KHDTK Rarung $(31.72 \%)$.

Research in the subtropics by Cao et al. (2020) shows that plant leaf litter is more important than root in maintaining the balance of the SOC. There is a strong positive correlation between litter biomass and SOC $(R=0.88)$ at significant level 0.05 . This research hints that plant leaf litter is important factor in maintaining the SOC. In this study, litter biomass in agroforestry sites ( 2 ton/ha) are between the monoculture site (1.2 ton/ha) and the secondary forest site (4.48 ton/ha). Studies by Pertiwi et al. (2021), Wulandari et al. (2021), Latifah et al. (2020), and Ivando et al. (2019) suggest that there is a correlation between plant richness and the litter biomass. A more complex agroforestry cropping pattern stored $100 \%$ more total above ground biomass than the simple cropping (Wulandari et al. 2021). There is no significant correlation between the RF index and the SOC content $(R=0.129)$ suggesting that the soil color in this study is influenced more by the organic materials than by the minerals consistent with finding from Minh et al. (2020). Therefore, we suggest that agroforestry sites should enrich the plant diversity to improve the SOC and carbon stocks.

In hilly areas, SOC is mainly governed by vegetation and altitude (Ramesh et al., 2019). Several studies have reported the positive correlation between altitude and SOC concentration mainly due to changes in temperature and vegetation characteristics (Massacessi, et al., 2020; Ramesh et al., 2019; Cardelli et al., 2019; Kobler et al., 2019; Tsozué et al., 2019). In this study, increase in elevation corresponds with increase in SOC concentration. The SOC concentration is between $3.7 \%$ (at 417 masl, monoculture stand) to $10.56 \%$ (at 803 masl, secondary forest).

Top soil organic carbon (SOC) is a significant factor influencing soil physical and chemical properties (Büneman et al., 2018) including soil fertility (King et al., 2020). Different land use affects SOC stocks (Ghimire et al. 2018; Sainepo et al. 2018). Improving SOC should be considered if the management goals include carbon sequestration, water regulation and improving productivity as SOC increases soil adsorptive capacity for nutrients and water and improves soil structure and its stability (Keesstra, et.al, 2016) by binding particles together into aggregates, which keeps the soil stable thereby increasing water infiltration and assisting in preventing soil compaction (Q., 2016).

According to Evans et al. (2020), the best measure to lengthen soil lifespans was to convert arable land to forest or to apply soil conservation measures such as cover cropping and hillslope terracing. The agroforestry in community forest and hortipark sites in this study were previously abandoned logged areas. Their soil properties are half of the secondary forest but better than a monoculture stand. This suggests that agroforestry may provide solution to lengthen soil lifespans and can be enhanced with soil conservation measures. Future studies can conduct experiment on various conservation measures and assess the impacts of such measures to soil properties. 


\section{CONCLUSIONS AND RECOMMENDATIONS}

Of the six management regimes studied, the secondary tropical dry forest poses the best soil properties (low BD, high SWC, high SOC, high litter biomass). Agroforestry soil properties figures are approximately half of the secondary forest. Improving the diversity of plants and applying conservation measures in agroforestry may enhance the soil properties particularly the SOC. This study indicates that understanding the soil properties might provide valuable information to improve the benefits of land sharing and better inform the landscape approach. We recommend further studies to assess more soil properties as they will provide better information for management intervention to enhance soil resources for generations to come.

\section{ACKNOWLEDGEMENT}

The authors would like to thank the Tahura Nuraksa, Hortipark Tastura, KHDTK Rarung, and local community in Karang Sidemen for their valuable support. The fund for this study received from Mataram University in $2020-2021$ is greatly appreciated.

\section{REFERENCES}

Abidin, M. H. Z., Saad, R., Ahmad, F., Wijeyesekera, D., \& Yahya, A.S. (2013). Soil Moisture Content and Density Prediction Using Laboratory Resistivity Experiment. IACSIT International Journal of Engineering and Technology, 5(6), 731-735. doi: https://www.doi.org/10.7763/IJET.V5.652

Anda, P. (2021). The reciprocal effect between soil water content and the soil bulk density on the growth and yield of onion (Allium cepa L.). Journal of Applied Agricultural Science and Technology, 5(2): 84-94. doi: https://doi.org/10.32530/jaast.v5i2.26

Afifah, N. G., Sumadio, W., Rustanto, A. (2021). Sustainable Livelihood Approach Farming Communities in Temoloyo River Basin, Kebumen Regency. Proceedings of $1^{\text {st }}$ International Conference on Sustainable Agricultural Socio-economic, Agribusiness, and Rural Development (ICSASARD, 2021). Advances in Economic, Business and Management Research. https://dx.doi.org/10.2991/aebmr.k.211214.033

Ansharyani, I. (2018). Barriers to Climate Change Adaptation and Sustainable Livelihoods: Conflicts in Knowledge, Policy and Management of Forests in Batulanteh Watershed, Sumbawa, Indonesia. Rutgers The State University of New Jersey, School of Graduate Studies. ProQuest Dissertations Publishing. https://www.proquest.com/openview/60e13a87838c132fad8a23b7ab13485e/1?pqorigsite $=$ gscholar $\& \mathrm{cbl}=18750 \&$ diss $=y$

Bickelhaupt. (2020). Soil pH: what it means. New York: Department of Forest and Natural Resources Management. SUNY College of Environmental Science and Forestry.

Bonfante, A., Terribile, F., \& Bouma, J. (2019). Refining physical aspects of soil quality and soil health when exploring the effects of soil degradation and climate change on biomass production: an Italian case study. Soil, 5(1), 1-14. doi: https://doi.org/10.5194/soil-5-1$\underline{2019}$ 
Bünemann, E. K., Bongiorno, G., Bai, Z., Creamer, R. E., De Deyn, G., de Goede, R., et al. (2018). Soil quality - a critical review. Soil Biol. Biochem. 120, 105-125. doi: 10.1016/j.soilbio.2018.01.030

Cao J; He X; Yuanqi Chen; Yuping Chen; Yanju Zhang; Shiqin Yu; Lixia Zhou; Zhanfeng Liu; Chenlu Zhang; Shenglei Fu. (2020). "Leaf Litter Contributes More to Soil Organic carbon Than Fine Roots in Two 10-Year-Old Subtropical plantations," Sci. Total Environ., vol. 704, pp. 0048-9697 [Online]. Available, doi: https://doi.org/10.1016/j.scitotenv.2019.135341.

Cardelli, V.; De Feudis, M.; Fornasier, F.; Massaccesi, L.; Cocco, S.; Agnelli, A.; Weindorf, D.C.; Corti, G. (2019). Changes of topsoil under Fagus sylvatica along a small latitudinalaltitudinal gradient. Geoderma 344, 164-178.

Chakraborty, K., \& Mistri, B. (2017). Estimation of Soil Compaction from Bulk Density and Its Effect on Crop Production: A Case Study of Burdwan - I Block, West Bengal. Indian Journal of Spatial Science, 8(2), 101-107.

Crane, J.F. and Balerdi. (2019). Banan growing in the Florida home landscape. Institute of Food and Agricultural Science. Extension University of Florida.

Evans, D.L., John N. Quinton, Jessica A. C. Davies, Jianlin Zhao, Gerard Govers. (2020). Soil lifespans and how they can be extended by land use and management change. Environmental Research Letters. doi: 10.1088/1748-9326/aba2fd

FAO. (2013). Payment for watershed services in Lombok, Indonesia: uncovering actors' strategies in a success story. Retrieved 14 December 2020.

Fujii, K. (2014). Soil acidification and adaptations of plants and microorganisms in Bornean tropical forests. Eco Res, vol. 29, pp. 371-381 [Online]. Available, doi : https://doi.org/10.1007/s11284-014-1144-3.

Ghosh, R. (2013). Effect of Soil Moisture in the Analysis of Undrained Shear Strength of Compacted Clayey Soil. Journal of Civil Engineering and Construction Technology, 4(1), 23-31. doi: https://www.doi.org/10.5897/JCECT12.070

Ghimire, P., Bhatta, B., Pokhrel, B., Kafle, G., and Paudel, P. (2018). Soil organic carbon stocks under different land uses in Chure Region of Makanwapun District, Nepal. SAARC J. Agri., 16(2): 13-23. doi: https://doi.org/10.3329/sja.v16i2.40255

Grossman, R.T. (2002). RB, Bulk density and linear extensibility. In: Dane JH, Topp C, Coeditors. (Method of soil analysis part 4 physical methods, Madison, Wisconsin. Soil Science Society of America Inc..

Hidayati, Eni. 2012. Farmers' Perception of Environmental Problems: A Case Study in Batulanteh Watershed, Indonesia. Proquest, UMI Dissertation Publishing. ISBN-10: 1249075904. ISBN-13: 978-1249075905.

Ivando, D., Banuwa, I. S., \& Bintoro, A. (2019). KARBON TERSIMPAN PADA BERBAGAI TIPE KERAPATAN TEGAKAN DI HUTAN RAKYAT DESA SUKOHARJO I KECAMATAN 
Soil Characteristics Of Six Forest... (Latifah S, et al)

SUKOHARJO KABUPATEN PRINGSEWU. Jurnal Belantara, 2(1), 53-61. https://doi.org/10.29303/jbl.v2i1.96

Ichsan, A. C., Silamon, R.F., Anwar, H., and Setiawan, B. (2013). Analisis kondisi sosial ekonomi masyarakat di sekitar kawasan hutan dengan tujuan khusus (KHDTK) Senaru dengan menggunakan pendekatan partisipatif. Jurnal Hutan Tropis, 1(3), 215-220. http://dx.doi.org/10.20527/iht.v1i3.1541

Keesstra, L., S.D., Bouma, J., Wallinga, J., Tittonel, P., Smith, P., Cerda, A., Montanarella, L., Quinton, J., Pachevsky, Y., Van der Putten, W.H., Bardgett, R., Moolenar, S., Mol, G., Jansen, B., and Fresco. (2016). The significance of soils and soil science towards realization of the United Nations Sustainable Development Goals. SOIL, vol. 2, pp. 111128 [Online]. Available: doi:10.5194/soil-2-111-2016.

Kim, Y.S. et al. (2018). Managing forests for global and local ecosystem services: A case study of carbon, water and livelihoods from eastern Indonesia. Ecosyst. Serv., vol. 31, pp. 153-168. doi: 10.1016/j.ecoser.2018.03.018.

King, A. E., Ali, G. A., Gillespie, A. W., and Wagner-Riddle, C. (2020). Soil organic matter as catalyst of crop resource capture. Front. Environ. Sci. 8:50. doi: 10.3389/fenvs.2020.00050

Kobler, J.; Zehetgruber, B.; Dirnböck, T.; Jandl, R.; Mirtl, M.; Schindlbacher, A. (2019). Effects of aspect and altitude on carbon cycling processes in a temperate mountain forest catchment. Landsc. Ecol. 34, 325-340.

Latifah, $S^{*}$, M. Husni Idris, Rato Silamon Firdaus, Niechi Valentino, Eni Hidayati, Nuraini, and Tedi Zulia Putra. (2020). VEGETATION CHARACTERISTICS AND CARBON STOCKS AFTER EARTHQUAKE IN FOREST FOR SPECIFIC PURPOSE (KHDTK) SENARU (Karakteristik Vegetasi dan Cadangan Karbon Pasca Gempa Bumi di KHDTK Senaru) Jurnal Penelitian Hutan dan Konservasi Alam. Vol 17, No.2, 173-189. doi: https://doi.org/10.20886/jphka.2020.17.2.173-189

Lauchli, A. and Grattan, S. R. (2012). Soil pH extremes. Plant Stress Physiology (ed. S. Shabala). CAB International. doi: 10.1079/9781845939953.0194

Manuri, S., C.A.S. Putra dan A.D. Saputra. (2011). Tehnik Pendugaan Cadangan Karbon Hutan. Merang REDD Pilot Project, German International Cooperation - GIZ. Palembang

Massacessi, L., Feudis, M. D., Leccese, A., Agnelli, A. (2020). Altitude and vegetation affect soil organic carbon, basal respiration and microbial biomass in Appenine Forest Soils. Forests, 11, 710. doi:10.3390/f11060710.

Minh, v. Q., Khoa, L. V., Du, T. T., Vu, P. T., Tri, L. Q. (2020). Prediction of orchard soils degradation using Munsell Soil Color. International Journal of Innovative Technology and Exploring engineering (IJITEE). 9(6); 338-343. doi: 10.35940/ijitee.F3482.049620

Nandini, R., A. Kusumandari, T. Gunawan, and R. Sadono. (2019). PERUBAHAN KUALITAS LINGKUNGAN PADA HUTAN KEMASYARAKATAN DI DAERAH ALIRAN SUNGAI BABAK, PULAU LOMBOK - Environmental Quality Changes in Community Forests in the Babak River Basin, Lombok Island. J. Penelit. Kehutan., vol. 3, no. I, pp. 43-50. 
Nepal, S., Neupane, N., Shrestha, H., Tharu, R.B. (2018). Upstream-downstream Linkages for Catchment Level Water Use Master Plans (WUMP) in the Mid-hills of Nepal; ICIMOD Working Paper 2017/23. doi: https://doi.org/10.53055/ICIMOD.746. https://lib.icimod.org/record/33716.

Nini, P., S., Haryanto, P.R., and Agus. (2012). Kajian mekanisme pambayaran jasa lingkungan penyediaan sumberdaya air (Studi Kasus di Kabupaten Lombok Barat dan Kota Mataram, Nusa Tenggara Barat). IPB University.

Pertiwi, Y. A. B., Nufus, M., Agustina, A., Rahmadwiati, R., Wicaksono, R. L., \& Nayasilana, I. N. (2021). STUDI KEANEKARAGAMAN, BIOMASSA DAN CARBON STOCK BAMBU DI TAMAN HUTAN RAYA K.G.P.A.A. MANGKUNAGORO I. Jurnal Belantara, 4(2), 140-152. https://doi.org/10.29303/jbl.v4i2.816

Queensland Government (Q.). $\quad$ (2016). $\quad$ "Soil Properties," https://www.qld.gov.au/environment/land/management/soil/soil-properties (accessed Dec. 13, 2020).

Ramesh, T., Nanthi S. Bolan, Mary Beth Kirkham, Hasintha Wijesekara, Manjaiah Kanchikerimath, Cherukumalli Srinivasa Rao, Sasidharan Sandeep, Jörg Rinklebe, Yong Sik Ok, Burhan U. Choudhury, Hailong Wang, Caixian Tang, Xiaojuan Wang, Zhaoliang Song, Oliver W. Freeman II. (2019). Chapter One - Soil organic carbon dynamics: Impact of land use changes and management practices: A review, Editor(s): Donald L. Sparks, Advances in Agronomy, Academic Press, Volume 156 (1-107), ISSN 0065-2113, ISBN 9780128175989, https://doi.org/10.1016/bs.agron.2019.02.001. (https://www.sciencedirect.com/science/article/pii/S0065211319300343)

Reed, S.T., and J, Deakin L. (2015). What are 'Integrated Landscape Approaches and how effectivelyhave they been implemented in the tropics: a systematic map protocol. Off. J. Collab. Environ. Evid., vol. 4, no. 2, [Online]. Available, doi: https://link.springer.com/article/10.1186/2047-2382-4-2.

Randi, S. (2018). Studi kandungan karbon lantai hutan pada tiga tingkat fraksi serasah dan hubungannya dengan keragaman tumbuhan hutan hujan tropis super basah di bukit Pinang-Pinang Padang. Diploma thesis, Universitas Andalas. http://scholar.unand.ac.id/33299/

Sainepo, B.M., Gachene, C.K. \& Karuma, A. (2018). Assessment of soil organic carbon fractions and carbon management index under different land use types in Olesharo Catchment, Narok County, Kenya. Carbon Balance Manage 13, 4 https://doi.org/10.1186/s13021-018-0091-7

Santana, DP. (1984). Soil formation in a toposequence of oxisols from Patos de Minas region, Minas Gerais State, Brazil. PhD thesis Purdue Univ., West Lafayette, IN.

Segura, J.A., R. A., Serrano, E., Pocasangre, L., Acuña, O., Bertsch, F., Stoorvogel, J. J., Sandoval. (2015). Chemical and microbiological interactions between soils and roots in commercial banana plantations (Musa AAA, cv. Cavendish). Sci. Hortic. (Amsterdam)., vol. 197, pp. 66-71 [Online]. Available, doi: https://doi.org/10.1016/i.scienta.2015.10.02.

Singh, D., B., Cattle, S.R., and Field. (2014). Edaphic Soil Science, Introduction to Encyclopedia 
of Agriculture and Food Systems, Academic Press.

Smith, G.D. (1960). A new soil classification scheme: progress report. Trans 7th int. Congr. Soil Sci 4: 105-111. https://eurekamag.com/research/013/935/013935855.php

Sulaeman, Suparto dan Eviati. (2005). PETUNJUK TEKNIS ANALISIS KIMIA TANAH, TANAMAN, AIR, DAN PUPUK. Balai Penelitian Tanah Departemen Pertanian.

Svensson, J., Neumann, W., Bjarstig, T., Zachrisson, A., and Thellbro, C. (2020). Landscape Approaches to Sustainability - Aspect of conflict, integration, and synergy in national public land use interest. Sustainability., vol. 12, no. 5113; doi:10.3390/su12125113

Terborgh J. (1992). Diversity and the tropical rain forest. Freeman, New York p. 31-104.

Tsozué, D.; Nghonda, J.P.; Tematio, P.; Basga, S.D. (2019). Changes in soil properties and soil organic carbon stocks along an elevation gradient at Mount Bambouto, Central Africa. Catena 175, 251-262.

UNEP. (2017). Landscape Approach Development. https://www.unenvironment.org/news-andstories/story/landscape-approach-development (accessed Dec. 12, 2020).

Wulandari, C., Harianto, S. p, \& Novasari, D. (2021). PENDUGAAN STOK KARBON PADA POLA TANAM AGROFORESTRI SEDERHANA DAN AGROFORESTRI KOMPLEKS DI KPH BATUTEGI, KABUPATEN TANGGAMUS. Jurnal Belantara, 4(2), 113-126. https://doi.org/10.29303/jbl.v4i2.632

Zhang, Y.Y., W. Wu, and H. Liu. (2019). Factors affecting variations of soil pH in different horizons in hilly regions. PLoS One, vol. 14, no. 6, pp. 1-13. doi: 10.1371/journal.pone.0218563. 